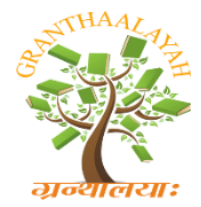

INTERNATIONAL JOURNAL OF RESEARCH GRANTHAALAYAH

A knowledge Repository

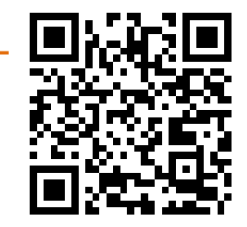

Science

\title{
POPULATION PATTERNS, BIOLOGY AND ECOLOGY OF BIVALVES FROM LAGOONS AND ROCKY SHORES IN GHANA
}

\author{
Fred A. Otchere ${ }^{* 1}$ \\ ${ }^{* 1}$ Department of Environment and Development Studies, Central University, P. O. Box 2305, \\ Tema, Ghana
}

\begin{abstract}
Seasonal sampling of bivalves from three lagoons and two rocky shores adjacent to these lagoons were studied. Two types of lagoons are found in Ghana; "open" and "closed" lagoons. Data presented include; total wet body weight, shell size, lipid content, condition index (CI) and total dry body weight as well as the effect of season on these bivalves. Three bivalves sampled showed similar patterns of variation in condition index and lipid content in response to seasonal change. Food availability and rainfall seem to control the patterns observed. Among the three bivalves, oysters have the highest lipid content $(81 \mathrm{mg} / \mathrm{g} \mathrm{dw})$ and cockles the least (48 $\mathrm{mg} / \mathrm{g} \mathrm{dw})$. Oysters had the highest CI (147) and mussels the least (124). Dry season CI were higher than the wet season. There were significant differences in the CI on size classes (all $\mathrm{p}<0.05$ ). There was no relationship between CI and lipid content of the bivalves. Geographically, bivalves from Benya lagoon have more lipid than those from Ningo and Sakumo lagoons. Seasonal differences at the stations might have been a reflection of the stage of gonad maturation or reproductive cycle.
\end{abstract}

Keywords: Bivalves; Lagoons; Ecology; Condition Index; Lipid Content; Shell Length; Seasonal Variation.

Cite This Article: Fred A. Otchere. (2020). "POPULATION PATTERNS, BIOLOGY AND ECOLOGY OF BIVALVES FROM LAGOONS AND ROCKY SHORES IN GHANA." International Journal of Research - Granthaalayah, 8(4), 53-66. https://doi.org/10.29121/granthaalayah.v8.i4.2020.7.

\section{Introduction}

Molluscs are invertebrates with an external shell and a living part consisting of a reduced head, a muscular foot and visceral hump (which contains all the main body organs). The mantle covers the visceral hump that secretes the shell and is hidden by the shell except at the edge. The mantle cavity is the space between the mantle and the visceral hump. Mollusca form the third largest animal phylum and is divided into seven classes. The class Bivalvia contains cockles, oysters, mussels and related forms with the shell divided into two halves, hinged together at the top and usually enclosing the whole body. The majority of bivalves are filter feeders. Three species used for the study: the West African bloody cockle, the mangrove oyster and the blue-green mussel 
belong to this class. These species were selected due to their ecological and commercial importance. In Ghana, of the different species of animals found on the sea shore and in shallow waters, one third are molluscs; they are more abundant than any other group (Yankson and Obodai, 1999; Ansa and Bashir, 2007; Krampah et al., 2019).

The West African bloody cockle, Anadara (Senilia) senilis is one of the most exploited species of bivalves found between Senegal and Angola. Its food value has been reported by several authors (Afinowi, 1975; Obodai and Yankson, 1999; Yankson, 2004; Ansa and Bashir, 2007). They have short siphons and live in the top 5 to $10 \mathrm{~cm}$ layer of sandy-mud and mud of lagoons and estuarine shores, extending sublittorally to places submerged between 2 and $3 \mathrm{~m}$ depth of water at low spring tides. They reach sexual maturity and spawn for the first time, when they are six months old and about $20 \mathrm{~mm}$ long. Breeding is continuous in the lagoons of Ghana. Sex ratios of the male to female approximately 1:1 in open lagoons and 1:2 in closed lagoons (Yankson, 1982, 2004; Ampofo-Yeboah, et all., 2009). Yoloye (1975) describes the same species from Nigerian lagoons as seasonal breeders and have a sex ratio of male to females to be 1:3. De la Cruz (1994) working on A. tuberculosa from Nicoya Gulf, Costa Rica, reported a sex ratio of 1:1. A. senilis occurs in waters with salinity over $10 \mathrm{psu}$ and also in hyperhaline waters above $38 \mathrm{psu}$, becoming exterminated when salinity is over $50 \mathrm{psu}$, but restocked from adjacent lagoon during the next rainy season. Their maximum length ranges between 100 and $150 \mathrm{~mm}$ depending on location and conditions (Yankson and Obodai 1999; Joiris, et al., 1998, 2000; Yankson, 2004).

The mangrove oyster Crassostrea tulipa abounds on the coast of West Africa between Senegal and Angola (Yankson, 1996; Obodai and Yankson, 1999; Sutton, et al., 2012). This species is found predominantly attached to the stilt roots of the red mangrove (Rhizohpora spp) which fringe the coastal waters of West Africa and any other hard surfaces they can find. It is deemed to have a considerable economic potential yet its cultivation in the sub-region is still at the experimental level. It is one of two main brackish water bivalves (the other being A. senilis) in West Africa. Ansa and Bashir, (2007) reported briefly on the condition and food value of the species (referred to as C. gasar) in the Nigerian waters. Yankson $(1996,2004)$ has given a recent and brief account of its sexual differentiation in two brackish water environments in Ghana. He describes the species as a continuous breeder in lagoons and as a seasonal one in estuaries. Size at maturity is $8 \mathrm{~mm}$ for males and $10 \mathrm{~mm}$ for females. This suggests that the majority of the oysters differentiate sexually and spawn first as males. The proportion of females increases with size until the sex ratio is approximately 1:1 in oysters measuring over $30 \mathrm{~mm}$ (Kamara et al., 1979; Obodai and Yankson, 1999; Sutton et al., 2012).

The blue-green mussels; marine bivalve Perna perna (epifauna colonizer) occurs on intertidal rocky shores, it abounds in a salinity range of 15 - $40 \mathrm{psu}$. Preferred climate is from tropical to subtropical with a temperature range of $15-35^{\circ} \mathrm{C}$ and occurs between Senegal and South Africa (Krampah et al., 2019). Limited distribution appears to be controlled by biological factors of predation and competition rather than inability to survive the conditions. They mature sexually in the first year but the size largely depends on local growth rate. Under optimum conditions it can attain lengths of $60-80 \mathrm{~mm}$ in two years. Reproduction is seasonal, but in some populations mussels may slowly dribble gametes more or less continuously over an extended part of the year. Life span ranges from 18 to 24 years depending on the ecological conditions (predation, 
competition etc.); (Yankson and Obodai. 1999; Yankson, 2004; Lamptey and Armah, 2008; Krampah et al., 2016).

Condition Index (CI) in which the amount of flesh is related to shell volume has been used extensively in scientific research and in the world of commercial fishery. Many different methods exist for measuring the CI (Galvao et al., 2015; Krampah et al., 2019). A commonly used index, however, is that in which dry flesh weight expressed as a proportion of the internal cavity volume of the shell (i.e., whole volume less the volume occupied by the actual shell valves). Methods using wet flesh weight or volume are less sensitive due largely to difficulty in standardizing degree of wetness. CI varies according to body size, season (Joiris et al., 1998; Micklem, et al., 2016), and level of parasitic infestation (Kent, 1979; Thiesen, 1987; Galvao et al., 2015) and with local environmental conditions especially the availability of food. In this study CI was used to assess the plumpness of bivalves; defined as the ratio between soft tissue dry weight $(\mathrm{mg})$ and shell length (mm) (Joiris et al., 2000; Lamptey and Armah, 2008 Krampah et al., 2016, 2019).

The aim of this study was to understand the influence of season on the biology (size and physiology of the animals) and ecology (type of lagoon, settlement and other human activities) of these bivalves. Data presented include: total wet fresh weight, shell size, lipid content, condition index, dry fresh body weight and the effect of season on these bivalve populations.

\section{Materials and Methods}

\subsection{Description of the Study Areas}

The lagoons in Ghana are of two main types: 'open' and 'closed' lagoons. The open lagoons (Benya and Ningo) are in contact with the sea throughout the year and therefore partly under tidal influence. Temperature and salinity ranges are 24 to $32^{\circ} \mathrm{C}$ and 10 to 40 psu respectively. The closed lagoons are cut off from the adjacent sea by a sand bar (about 40 meter wide) for the greater part of the year. Temperature and salinity ranges are: 27 to $34^{\circ} \mathrm{C}$ and 27 to 70 psu respectively (as in Sakumo lagoon). The rocky shores adjacent to these lagoons are the cliff type/gentle sea shore with sea level/tidal markings.

\subsection{Sampling Procedure}

Samples of Anadara (Senilia) senilis (cockles; $\mathrm{n}=550$ ), and Crassostrea tulipa (oysters; $\mathrm{n}=360$ ) from three lagoons and Perna perna (mussels; $\mathrm{n}=210$ ) from two rocky shores adjacent to these lagoons, were collected (hand-picked randomly) in October 2016 and February 2017 wet and dry seasons, respectively.

\subsection{Sample Treatment}

For each bivalve, the total weight was determined with a weighing balance of $0.001 \mathrm{~g}$ precision. Then length and width were measured with a veneer caliper of a minimum reading precision of $0.1 \mathrm{~mm}$. Total flesh of the bivalve was excised, weighed and deep frozen. Soft tissue dry weight was determined after samples were freeze-dried for 24 hours. Ring counts were conducted to determine the approximate age range of the samples. Lipid content was determined after Soxhlet 
extraction with hexane/acetone (9/1) for ten (10) hours. It was computed as the difference between the weight of the beaker, after the evaporation of the hexane/acetone extract and the weight of the beaker, after the dissolution of the lipid in hexane (to the precision of $0.0001 \mathrm{~g}$ ).

\subsection{Data Management and Analysis}

Correlations, simple linear regressions and frequency distributions were used to compare locations and seasons. Lipid content of bivalves were compared between stations for the same species and among different species of the same station as well as the temporal variations. The size classes were based on shell length (less than $30 \mathrm{~mm}$ as small, $30-40 \mathrm{~mm}$ as medium and greater than 40 $\mathrm{mm}$ as large) for cockles and mussels; while shell length of (less than $40 \mathrm{~mm}$ as small, 40-50mm as medium and greater than $50 \mathrm{~mm}$ as large) for oysters.. The results were compared within class (from different locations and species) and among classes using Mann-Whitney-U and KruskalWallis test of significance as the distributions were non-normal and skewed. Significance levels were fixed at 0.05 as significant and 0.01 as highly significant, median values (min - max) were presented.

\section{Results}

\subsection{The Bloody Cockle; Anadara (Senilia) senilis}

\section{Shell Size and Flesh Weight}

Frequency distribution diagram of shell length $(n=550)$ is positively skewed as shown in figure 1. The length of the bivalves ranged between 16 and $64 \mathrm{~mm}$ and mean was $32 \pm 9 \mathrm{~mm}$; median length is $29 \mathrm{~mm}$. Joiris and Azokwu (1999) working on A. senilis from Bonny estuary (Nigeria) reported a range between 22 and $93 \mathrm{~mm}$ and a median of $45 \mathrm{~mm}$. While de la Cruz (1994) recorded a shell length range of $28-67 \mathrm{~mm}$, a median value of $47 \mathrm{~mm}$ for A. tuberculosa from Costa Rica. With Anadara (Senilia) senilis, shell weight constitutes about $80 \%$ of the mean total weight of the bivalve. This percentage tended to increase with size, meaning continuous deposition of $\mathrm{CaCO}_{3}$ during the lifetime of the cockle. The simple regression analysis between length and shell thickness shows a highly significant correlation $(\mathrm{r}=0.89 ; \mathrm{p}<0.001)$. Observations included: shells possessing conspicuous and regularly spaced rings reminiscent of the winter rings on the shells of several temperate bivalve species. Random ring count results indicated that the age of the cockles sampled lay between $<1$ and 7 years. Mean dry weight to fresh weight ratio was $0.15 \pm 0.03$ for the wet season and $0.16 \pm 0.03$ for the dry season. There was a significant curve-linear relationship between bivalve shell length and dry flesh weight (fig. 2). 


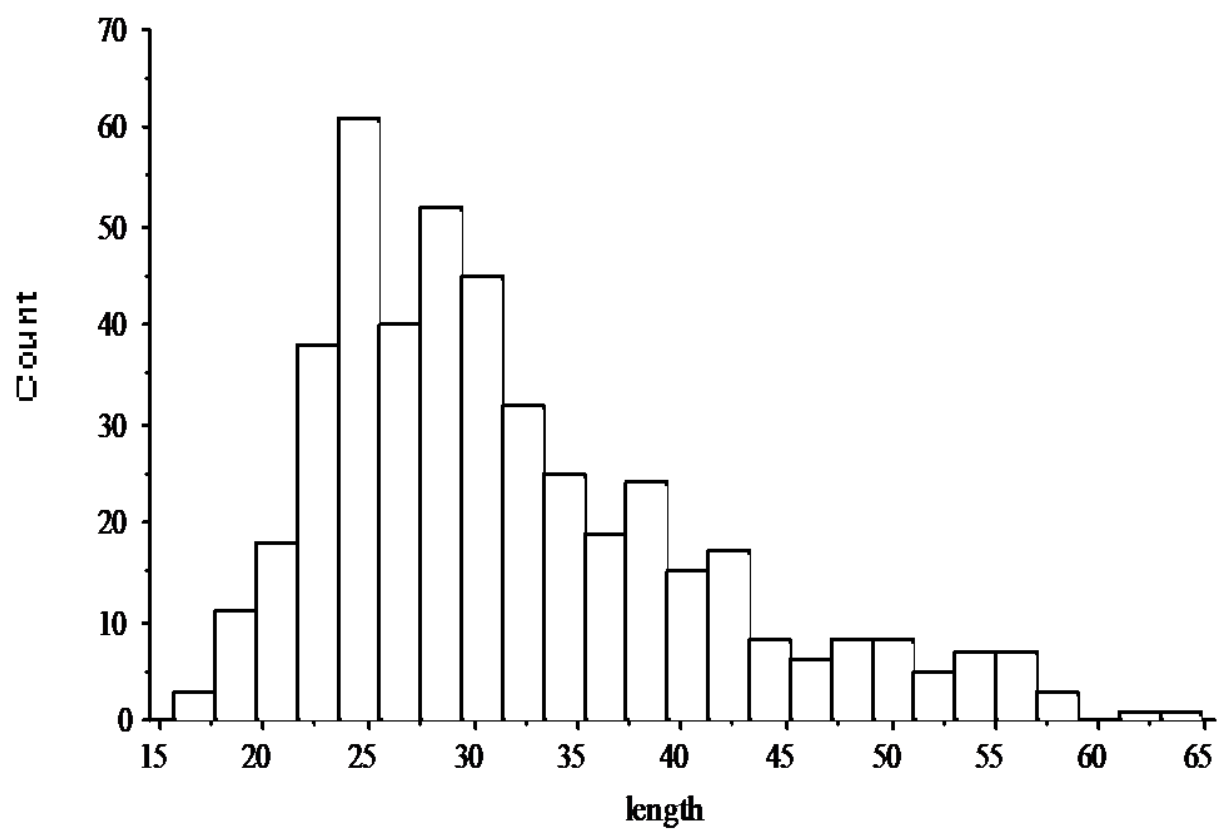

Figure 1: Length (mm) frequency distribution of Anadara (Senilia) senilis from the lagoons in Ghana.

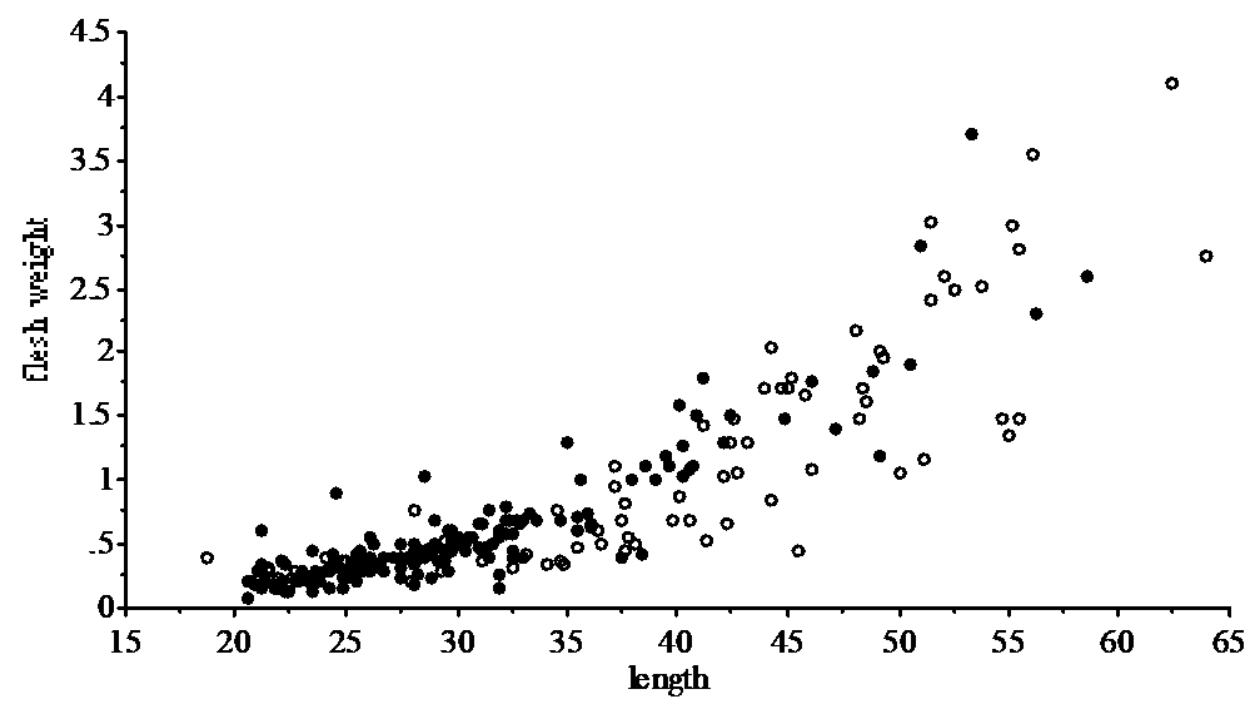

Figure 2: Relationship between cockle length $(\mathrm{mm})$ and dry flesh weight $(\mathrm{g})$ (wet season: circles and dry season: dots).

\section{Lipid Content}

Median lipid content for all locations and both seasons $(\mathrm{n}=62)$ was $48 \mathrm{mg} / \mathrm{g} \mathrm{dw}$ and ranged between 13 and $160 \mathrm{mg} / \mathrm{g} \mathrm{dw}$. No relationship between size and lipid content was found ( $\mathrm{p}>0.05)$. Visual inspection of table 1 reveals no significant seasonal variation of lipid content in the cockles (dry season: $40 \mathrm{mg} / \mathrm{g} \mathrm{dw}$ and wet season: $46 \mathrm{mg} / \mathrm{g} \mathrm{dw}$ values pooled together for all stations). 
Benya cockles tended to contain more lipid (107 and $71 \mathrm{mg} / \mathrm{g} \mathrm{dw}$ ) than Ningo $(24$ and $31 \mathrm{mg} / \mathrm{g}$ $\mathrm{dw}$ ) and Sakumo (38 and $35 \mathrm{mg} / \mathrm{g} \mathrm{dw}$ ) during the dry and wet seasons respectively. This could be based on the fact that Benya lagoon is in an urbanized area and might have more nutrients entering (anthropogenic sources) and hence be more productive. Joiris and Azokwu (1999) working on A. senilis from Bonny estuary (Nigeria) reported lipid content range of 15 - $95 \mathrm{mg} / \mathrm{g} \mathrm{dw}$ and median value of $46 \mathrm{mg} / \mathrm{g} \mathrm{dw}$. They reported no seasonal difference in lipid content. Similarly de la Cruz (1994) did not find any significant difference in lipid content of A. tuberculosa for both wet and dry seasons. Based on size class there was no difference in lipids content between the three size classes (median values; small: 48, medium: 43 and large: $48 \mathrm{mg} / \mathrm{g} \mathrm{dw}$ ) pooled together for both seasons (all $\mathrm{p}>0.05)$.

Table 1: Lipid content (mg/g dw) in cockles from the three lagoons: median values (min-max) and $\mathrm{n}=$ number of samples; Benya and Ningo: open and Sakumo: closed lagoon.

\begin{tabular}{|l|l|l|l|l|}
\hline Lagoons & Dry season & $\mathbf{n}$ & Wet season & $\mathbf{n}$ \\
\hline Benya & $107(38-160)$ & 8 & $71(45-122)$ & 31 \\
Ningo & $24(15-114)$ & 6 & $31(30-39)$ & 3 \\
Sakumo & $38(33-43)$ & 4 & $35(13-74)$ & 10 \\
All stations & $40(15-160)$ & 18 & $46(13-122)$ & 44 \\
\hline
\end{tabular}

\section{Condition Index (CI)}

The median CI calculated for all cockles was 137. Median CI for wet and dry seasons were 121 and 154 respectively (table 2). The CI for the dry season was higher than the index calculated for the wet season, suggesting that cockles sampled during the dry season were plumper than those of the wet season, this being statistically significant at $\mathrm{p}<0.01$. The seasonal difference in $\mathrm{CI}$ in the cockles might be due to the reproductive cycle as most cockles spawn during the wet season hence the reduced 'dried flesh' weight, compared to the dry season (except in Sakumo: due to size effect and type of lagoon; table 2). The difference was not significant as shown in figure 3. There was a significant difference between the size classes (all $\mathrm{p}<0.01$ ); the bigger the bivalve the higher the CI.

Table 2: Condition index measured for A. senilis from lagoons in Ghana, showing seasons; median values ( $\min -\max$ ); $\mathrm{n}=$ number of samples. Benya and Ningo: open and Sakumo: closed lagoon.

\begin{tabular}{|l|l|l|l|l|l|l|}
\hline Lagoons & Dry season & Length $(\mathbf{m m})$ & $\mathbf{n}$ & Wet season & Length (mm) & n \\
\hline Benya & $154(44-553)$ & $31(21-49)$ & 129 & $115(56-430)$ & $37(19-39)$ & 142 \\
Ningo & $371(210-658)$ & $42(19-59)$ & 26 & $243(165-332)$ & $42(36-49)$ & 23 \\
Sakumo & $126(77-176)$ & $25(17-33)$ & 40 & $302(62-655)$ & $41(21-62)$ & 45 \\
All & $154(44-658)$ & $29(17-59)$ & 195 & $121(56-655)$ & $39(19-62)$ & 210 \\
\hline
\end{tabular}




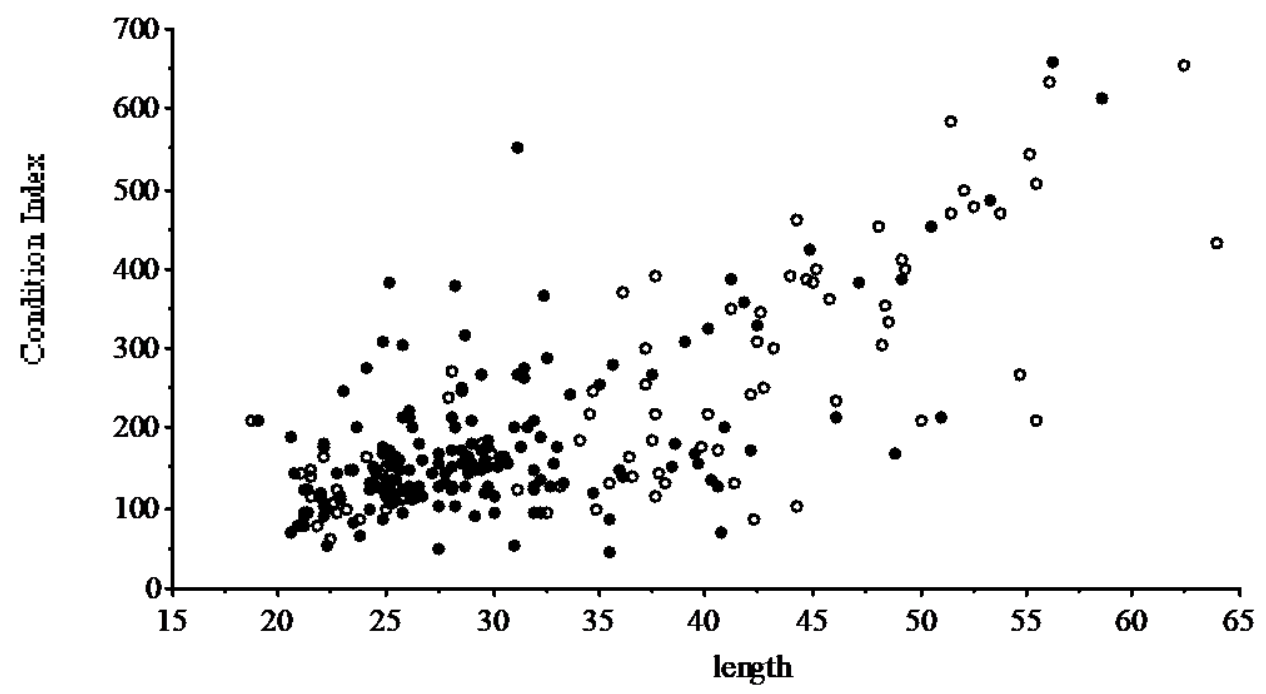

Figure 3: Relationship between CI and length ( $\mathrm{mm})$ of cockles from lagoons in Ghana (pooled values); dry (dots) and wet (circles) seasons.

\subsection{Mangrove Oyster: Crassostrea tulipa}

\section{Shell Size and Flesh Weight}

Frequency distribution diagrams of length and flesh weight $(n=356)$ are shown in figures 4 and 5. The length of oysters ranged between 18 and $80 \mathrm{~mm}$ and the median was $44 \mathrm{~mm}$. Median flesh fresh weight was $6.5 \mathrm{~g}$ and a range of 0.4 to $30 \mathrm{~g}$. The average dry weight fresh weight ratio was $0.12 \pm 0.04$ making $88 \%$ of the flesh weight to be moisture. Distribution curve for length was close to normal. The length frequency curve for oysters compared to that of cockles showed that oysters might be less exploited, or if the exploitation rate was as high as in cockles, it was general for all sizes.

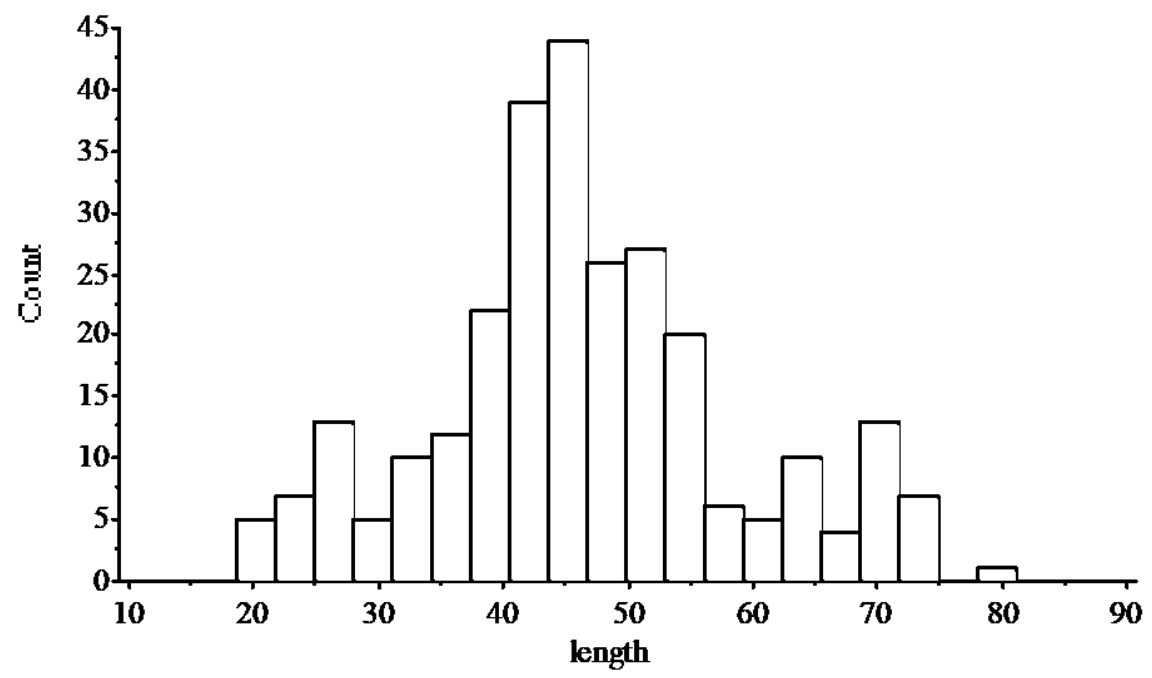

Figure 4: Length (mm) frequency distribution curve for oysters from the lagoons in Ghana. 


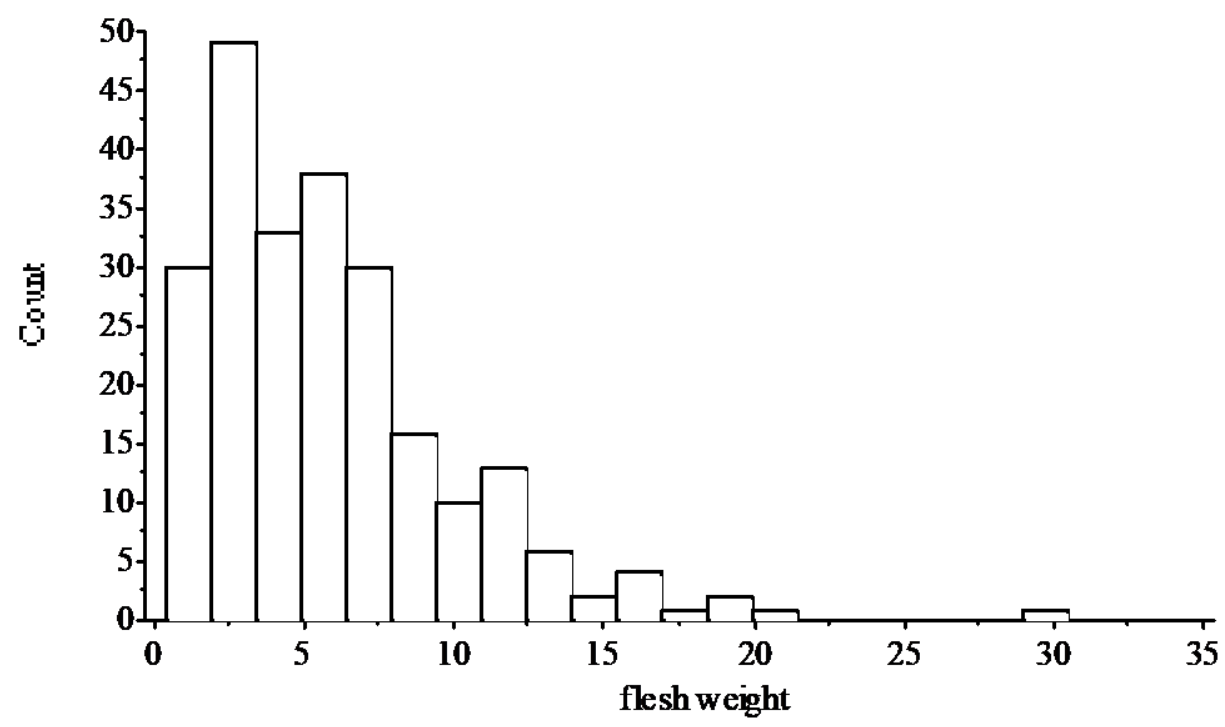

Figure 5: Flesh weight (g) distribution curve for oysters collected from the lagoons in Ghana.

\section{Lipid Content}

The median lipid content for all locations and both seasons was $81 \mathrm{mg} / \mathrm{g} \mathrm{dw}(\mathrm{n}=39)$, and ranged between 34 and $300 \mathrm{mg} / \mathrm{g}$ dw. Table 4 reveals no significant seasonal variation $(\mathrm{p}=0.4)$ of lipids content in oysters, even if dry season values tended to be higher (median $83 \mathrm{mg} / \mathrm{g} \mathrm{dw}$ ) than wet season values ( $77 \mathrm{mg} / \mathrm{g} \mathrm{dw}$, pooled values). Spatially, Benya oysters had more lipid (192 and 110 $\mathrm{mg} / \mathrm{g} \mathrm{dw}$ ) than Ningo (81 and $77 \mathrm{mg} / \mathrm{g} \mathrm{dw}$ ) and Sakumo (67 and $76 \mathrm{mg} / \mathrm{g} \mathrm{dw}$ ) for the dry and wet seasons respectively. There was no difference in lipid content between the size classes: $62 \mathrm{mg} / \mathrm{g}$ $\mathrm{dw}$ for medium and $75 \mathrm{mg} / \mathrm{g} \mathrm{dw}$ for large size (pooled values; $\mathrm{p}>0.05$ ). The correlation between size of oysters and lipid content showed no significant relationship ( $p>0.05)$. Those values above $100 \mathrm{mg}$ might be oysters with matured gonads and not spawned yet.

Table 4: Seasonal and locational trend in lipid content $(\mathrm{mg} / \mathrm{g} \mathrm{dw})$ in oysters from Ghana lagoons; median values ( $\min -\max ) \mathrm{n}=$ number of samples. Benya and Ningo: open and Sakumo: closed.

\begin{tabular}{|l|l|l|l|l|}
\hline Lagoons & Dry season & $\mathbf{n}$ & Wet season & $\mathbf{n}$ \\
\hline Benya & $192(75-300)$ & 9 & 110 & 1 \\
Ningo & $81(66-144)$ & 10 & 77 & 1 \\
Sakumo & $67(34-90)$ & 9 & $76(57-91)$ & 9 \\
All stations & $83(34-300)$ & 28 & $77(57-110)$ & 11 \\
\hline
\end{tabular}

\section{Condition Index}

The median condition index (CI pooled, all values) was 147 and ranged from 35 to $446(n=231)$; wet and dry seasons values were 128 and 177 respectively as in table 5 . The CI for the dry season was higher than the wet season and statistically significant $(\mathrm{p}<0.05)$. There was no relationship between the CI and the size of the oysters (figure 6). On the other hand there was a highly significant difference $(\mathrm{p}<0.01)$ between CI of Benya oysters (lower) and that of Ningo and/or Sakumo samples (for both seasons). 
Table 5: Seasonal and locational trends in the condition index (CI) for oysters from the three lagoons; median values (min-max); $\mathrm{n}=$ number of samples. Benya and Ningo: open and

Sakumo: closed.

\begin{tabular}{|l|l|l|l|l|l|l|}
\hline Lagoons & Dry season CI & Length (mm) & n & Wet season CI & Length (mm) & n \\
\hline Benya & $165(94-342)$ & $47(32-69)$ & 44 & $79(35-281)$ & $34(20-55)$ & 36 \\
Ningo & $203(84-289)$ & $41(27-70)$ & 31 & $146(93-201)$ & $41(21-71)$ & 12 \\
Sakumo & $249(211-446)$ & $44(23-71)$ & 31 & $133(99-245)$ & $43(22-70)$ & 77 \\
All & $177(84-446)$ & $44(23-71)$ & 106 & $128(35-281)$ & $39(20-71)$ & 125 \\
\hline
\end{tabular}

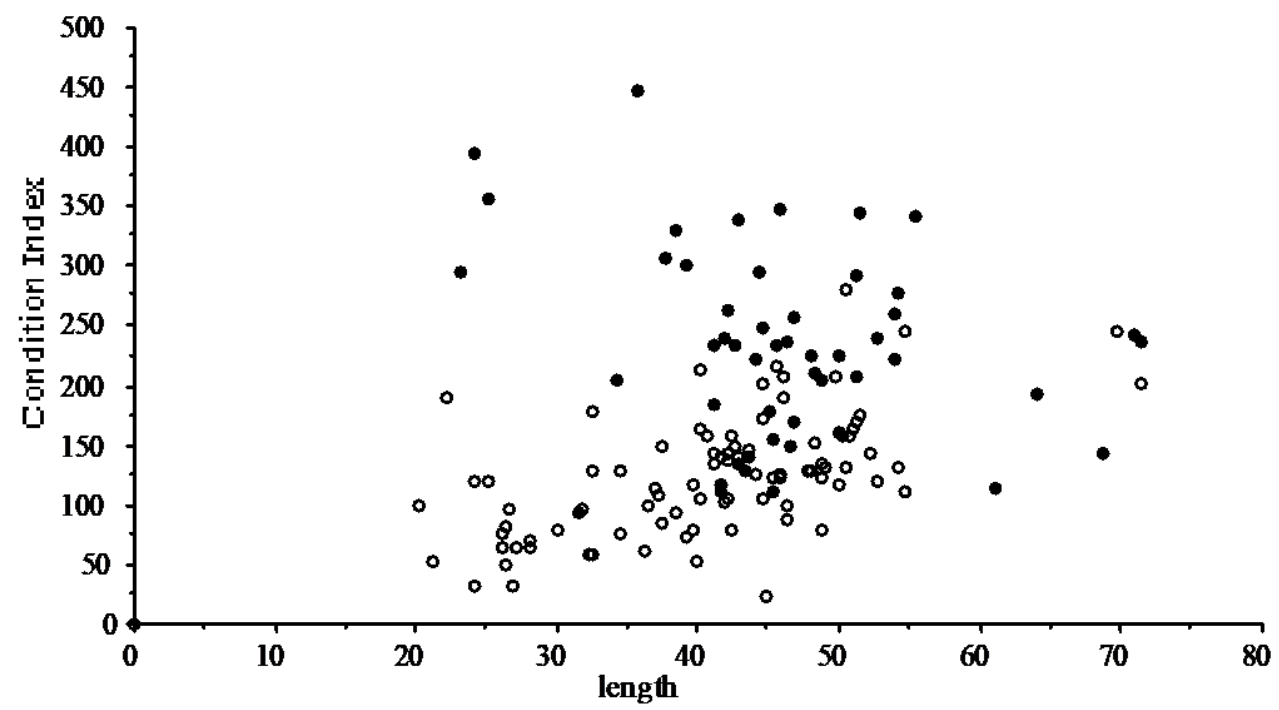

Figure 6: Relationship between length (mm) and CI of oysters: dry season; dots and wet season; circles.

\subsection{Blue-green Mussel: Perna perna}

\section{Shell Size and Flesh Weight}

Frequency distribution diagrams of length $(n=207)$ and fresh weight $(n=156)$ are shown in figures 7 and 8. Length distribution was close to normal with a coefficient of variation of $10.2 \%$. Median length was $38 \mathrm{~mm}$ (pooled values) and ranged from 26 to $55 \mathrm{~mm}$. The median lengths for the mussels from Benya were 38 and $39 \mathrm{~mm}$ and Sakumo were 37 and $33 \mathrm{~mm}$ dry and wet seasons respectively. The flesh weight distribution curve was skewed to the right. The fresh flesh weight median value was $1.5 \mathrm{~g}$; range: 1 to $6 \mathrm{~g}$. The dry weight/fresh weight ratio was $0.13 \pm 0.05$. From the length frequency histogram (fig. 7) it could be deduced that samples collected for the study were all less than two years old, an indication of over exploitation/high fishing pressure on this bivalve at these locations. 


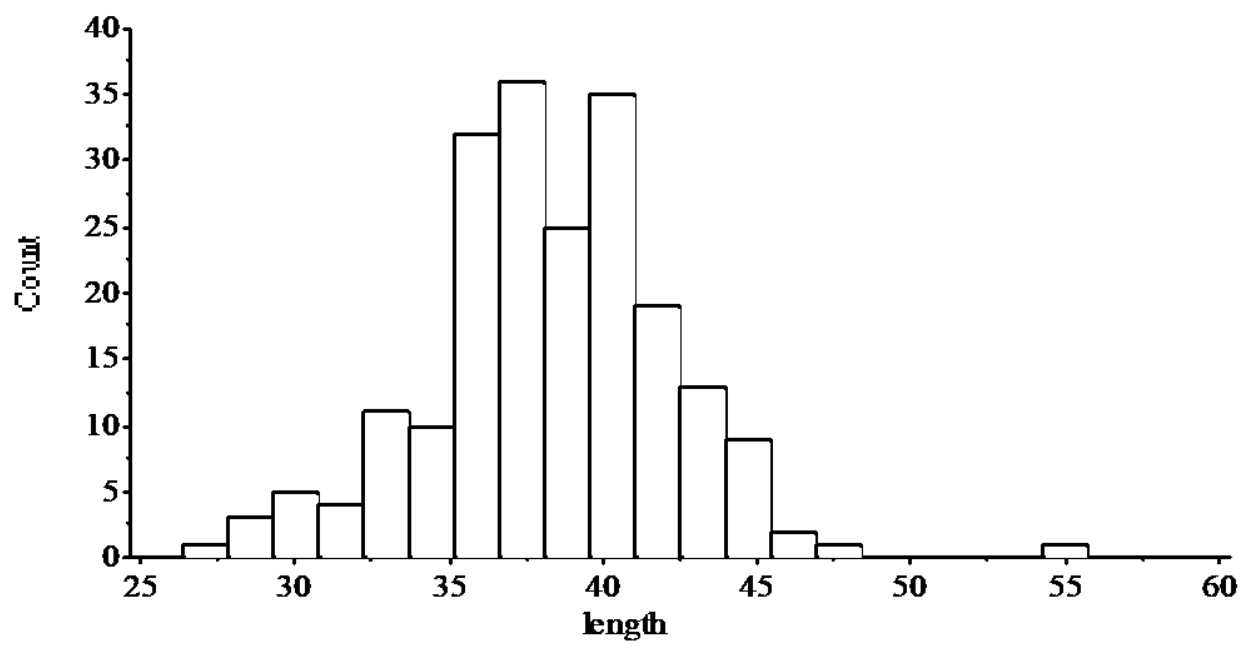

Figure 7: Length (mm) frequency distribution curve for the mussel Perna perna from Ghana.

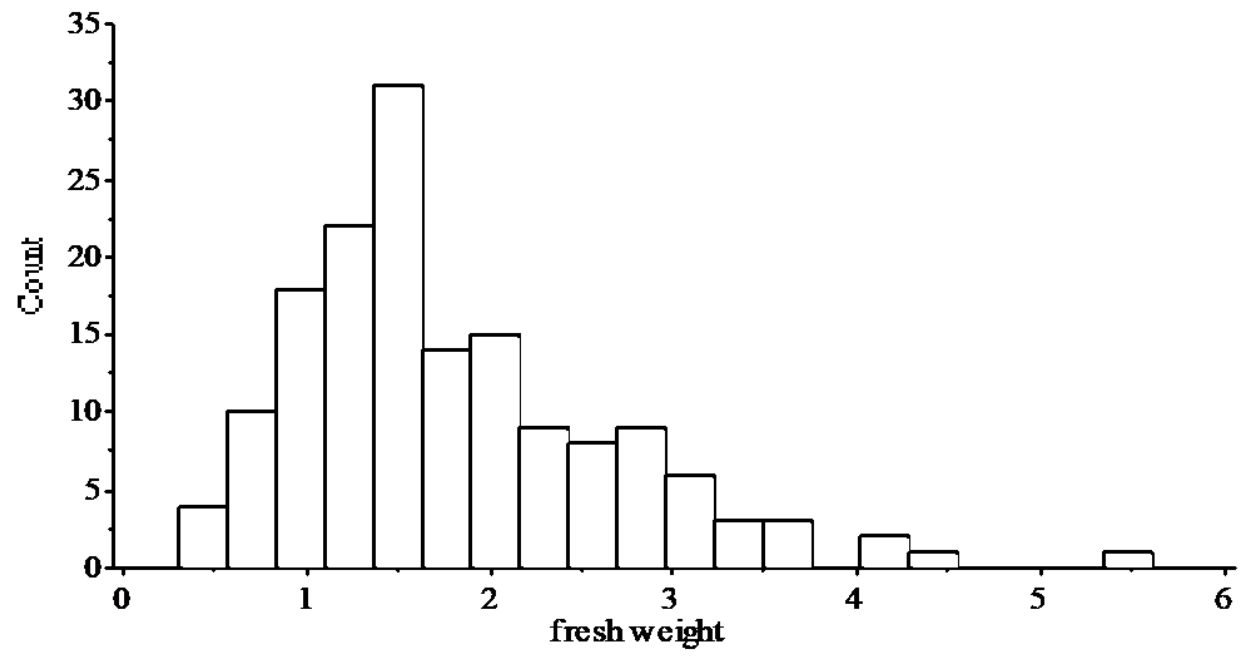

Figure 8: Fresh weight (g) frequency distribution curve for the mussel Perna perna from Ghana.

\section{Lipid Content}

The median lipid content for the two locations and seasons $(\mathrm{n}=13)$ was $72 \mathrm{mg} / \mathrm{g} \mathrm{dw}$ and ranged from 49 to $119 \mathrm{mg} / \mathrm{g} \mathrm{dw}$. The low number of samples analyzed does not allow a good comparison between stations and seasons.

Table 6: Lipid content (mg/g dw) in mussels (P. perna) from the coast of Ghana; median values ( $\min -\max ) ; \mathrm{n}=$ number of samples.

\begin{tabular}{|l|l|l|l|l|}
\hline Stations & Dry season & n & Wet season & n \\
\hline Benya & 115 & 1 & $90(60-119)$ & 7 \\
Sakumo & $53(49-72)$ & 5 & - & \\
\hline All stations & $72(49-119)$ & 13 & & \\
\hline
\end{tabular}




\section{Condition Index (CI)}

The median CI for the mussel was 128 ( $\mathrm{n}=189$; range: 48 - 252). The CI values for wet (121) and dry (129) seasons were similar to patterns reported in the other bivalves (in this study); the dry season compared to the wet season was not significant in this case as in table 7. The CI has no size effect and no spatial difference, possibly due to the limited size range used for the study (26 - 55 $\mathrm{mm})$.

Table 7: Seasonal and spatial trends in condition index for Perna perna from the coast of Ghana; median values (min-max); $\mathrm{n}=$ number of samples.

\begin{tabular}{|l|l|l|l|l|l|l|}
\hline Stations & Dry season CI & Length $(\mathbf{m m})$ & n & Wet season CI & Length $(\mathbf{m m})$ & $\mathbf{n}$ \\
\hline Benya & $106(48-246)$ & $38(26-55)$ & 80 & $125(64-232)$ & $39(29-46)$ & 58 \\
Sakumo & $158(120-221)$ & $37(36-40)$ & 19 & $135(67-252)$ & $33(28-38)$ & 32 \\
All stations & $129(48-246)$ & $38(26-55)$ & 99 & $121(64-252)$ & $37(28-46)$ & 90 \\
\hline
\end{tabular}

\section{Discussion}

Bivalves from three lagoons and two rocky shores were studied to determine the patterns (length, flesh weight, etc.) of their populations. The aim was to understand the influence of season on the biology (size and physiology of the animals) and ecology (type of lagoon, settlement and other human activities) of these bivalves. The three bivalves showed a similar pattern of variation in condition index and lipid content in response to seasonal changes with no significant influence due to location and ecology of the area (that is "open" verses "closed" lagoons or marine verses blackish water conditions). Food availability and rainfall seem to control the pattern observed. Among the three bivalves, oysters have the highest lipid content $(81 \mathrm{mg} / \mathrm{g} \mathrm{dw})$ and cockles the least $(48 \mathrm{mg} / \mathrm{g} \mathrm{dw})$ on the average. Geographically, bivalves from Benya have more lipid than those from Ningo and Sakumo lagoons: 107 and $71 \mathrm{mg} / \mathrm{g} \mathrm{dw}$ for cockles; 192 and $110 \mathrm{mg} / \mathrm{g} \mathrm{dw}$ for oysters and 115 and $90 \mathrm{mg} / \mathrm{g} \mathrm{dw}$ for mussels, dry and wet seasons respectively. In all three bivalves (from Benya), dry season lipid content were significantly higher than the wet season ones. This difference may be due to the ecology of the area; mainly as a result of food availability (Delbeke et al., 1991; Krampah et al., 2016). Benya lagoon (a major fishing harbour in Ghana) may be most productive than Sakumo and Ningo lagoons. In addition, in-flow from three streams to Benya lagoon with eroded organic materials from farms and villages around might have come along with nutrients and this may be the reason for the difference (Yankson and Obodai. 1999; Krampah et al., 2016). Seasonal differences may be a reflection of the stage of gonad maturation or reproductive cycle (de la Cruz, 1994; Joiris, et al. 2000). Comparing the dry weight/fresh weight ratios, cockles had the highest value $(0.15)$ and oysters the least $(0.12)$. The difference between the three species was, however, not significant. Temporally there was no difference between the ratios (e.g., cockles; wet season- 0.15 and dry season- 0.16 ).

Oysters had the highest CI (147) and mussels the least (124). The dry season CI (all stations and species) were higher than in the wet season which may be dependent on complex interaction of more food availability, high temperature, growth and reproductive processes just after the rainy season. There were significant differences in the CI on size classes (all p < 0.05): the bigger the bivalve the higher the $\mathrm{CI}$. There was no relationship between $\mathrm{CI}$ and lipid content of the bivalves. Bivalves from Benya showed the lowest CI: 154 and 115 for cockles, 165 and 79 for oysters and 106 and 125 in mussels for dry and wet seasons respectively. Low indices of the bivalves from 
Benya could suggest a higher exploitation rate at this location due to higher human population density: Benya an urban area compared to Ningo and Sakumo. There were seasonal differences in CI for both cockles and oysters (dry season being higher than the wet season) but no temporal difference for mussels. The probable reason for this increased CI (in dry season) might be due to a period of gonad maturation. For matured gonads account for about $40 \%$ of the total dry soft tissue weight of bivalves (Ampofo-Yeboah, et al., 2009 Krampah et al., 2016; Galvao et al., 2015). However, there was no difference in CI between open and closed lagoons. The CI for this study was of the same order of magnitude as the CI calculated for Nigerian cockles: 183 and 247 for both dry and wet seasons respectively (Joiris et al., 1998,).

Table 8: Synopsis: Length $(\mathrm{mm})$, fresh flesh weight $(\mathrm{g})$, lipid content $(\mathrm{mg} / \mathrm{g})$, dry weight/fresh weight ratio and CI of bivalves from Ghana; median ( $\min -\max ), \mathrm{n}=$ number of samples.

\begin{tabular}{|l|c|c|c|}
\hline Species > & Anadara (Senilia) senilis & Crassostrea tulipa & Perna perna \\
\hline Length & $29(16-64)$ & $44(18-80)$ & $38(26-55)$ \\
Fresh weight & $2.88(1-20)$ & $6.5(1-30)$ & $1.5(1-6)$ \\
Lipid content & $48(13-160)$ & $81(34-300)$ & $72(49-119)$ \\
Condition index & $137(44-658)$ & $147(35-446)$ & $124(48-252)$ \\
dw/fw ratio & $0.15(0.08-0.23)$ & $0.12(0.05-0.35)$ & $0.13(0.07-0.24)$ \\
$\mathrm{n}$ & 550 & 360 & 210 \\
\hline
\end{tabular}

De la Cruz 1994 recorded CI of 124 in Anadara tuberculosa from Costa Rica, similar to the values in this work (table 8). A study carried out on oysters from different coastal areas in Kenya, revealed that the areas with more organic matter, have oysters with higher CI; the authors concluded that the organic matter input might have enhanced the growth and hence the CI of the oysters (Delbeke et al., 1991; Krampah et al., 2019).

Length distribution curves for cockles and oysters approached a normal curve but skewed positively, which signifies that these bivalves are less exploited on the coast of Ghana than the mussels. In addition, from the length frequency histogram (fig. 7) it could be deduced that samples collected for the study were all less than two years old, an indication of over exploitation/high fishing pressure on this bivalve (mussels) at these locations. The skewness of the histograms for shell length may be due to the following reasons among others: it may be the size range (more than $30 \mathrm{~mm}$ ) that might have been most exploited along the coast and also the size at which mortality/predation is high. There were no differences in sizes between open and closed lagoons. These distribution patterns may reflect the degree of fishing pressure on these bivalves (mussel > cockle > oyster) and also bivalve preference in Ghana may follow such order. It is important to reduce the fishing pressure during certain periods of the year to give bivalves more time to grow to commercial sizes and in so doing less time will be spent looking for larger bivalves.

\section{Conclusion}

In conclusion, seasonal or geographical differences detected in the CI, lipid content and flesh weight could be explained by conditions such as food availability, life cycle of the bivalves and fishing pressure during the seasons. From distribution curves, it may reflect the size range (more than $30 \mathrm{~mm}$ ) that might have been most exploited/preferred along the coast and also the size at which mortality/predation is high. Based on the results of this study, bivalve preference in Ghana 
may follow this order; mussel > cockle > oyster; mussels being the most preferred bivalve and oysters the least.

\section{References}

[1] Afinowi MA. The biology of Anadara senilis and Gryphaea (Crassostrea) Gasar in West Africa waters. In: FAO/CIFA symposium on Aquaculture in Africa, Accra, Ghana. 1975; 1-120.

[2] Ampofo-Yeboah A, Owusu-Frimpong M, Yankson K. Gonad development in the freshwater oyster, Etheria elliptica (Bivalvia: Etheriidae) in northern Ghana. African Journal of Aquatic Science. 2009; 34: 195-200.

[3] Ansa, EJ, RM Bashir. Fishery and culture potentials of the mangrove oyster (Crasosstrea gasar) in Nigeria. Research Journal of Biological Sciences. 2007; 2:392-394.

[4] De la Cruz EM. Stable pollutants in the bivalve Anadara tuberculosa from the Nicoya Gulf Costa Rica -organochlorines and metals- Ph. D. thesis, Free University of Brussels (VUB). 1994

[5] Delbeke K, Omolo O, Umani, Anyango. Assessment of pollution impact on mangrove oyster Crassostrea cucullata. In: Progress report- Kenyan Belgium project in Marine Sciences - "Higher Institute for Marine Sciences". 1991; pp: 106-112.

[6] Galvao P, Longo R, Paulo J, Torres JPM, Malm O. Estimating the potential production of the brown mussel Perna perna (Linnaeus, 1758) reared in three tropical bays by different methods of condition indices. Journal of Marine Biology. 2015; Article ID 948053 (11 pp).

[7] Joiris CR, Azokwu MI, Otchere FA, Ali IB. Mercury in the bivalve Anadara (Senilia) senilis from Ghana and Nigeria. The Science of Total Environment. 1998; 224:181-188.

[8] Joiris CR, Azokwu MI. Heavy metals in the bivalve Anadara (Senilia) senilis from Nigeria. Marine Pollution Bulletin. 1999; 40(5):457-460.

[9] Joiris CR, Holsbeek L, Otchere FA. Mercury in the bivalves Crassostrea tulipa and Perna perna from Ghana. Marine Pollution Bulletin. 2000; 38(7): 618-622.

[10] Kent RML. The influence of heavy infestation of Polydora ciliata on the flesh content of Mytilus edulis. Journal of Marine Biological Association of UK. 1979; 59:289-297.

[11] Kamara AB, McNeil KB, Quayle DB. Tropical mangrove oyster culture: Problems and prospects. In: Advances in Aquaculture, ed. Pillay, T.V.R. and Dill, W.A. F.A.O. Technical Conference on Aquaculture. Kyoto, Japan. 1979; 344-348.

[12] Krampah EA, Yankson K, Blay J. Aspects of reproduction of the brown mussel Perna perna at the Iture rocky beach near Cape Coast, Ghana. African Journal of Marine Science. 2016;38(4):503512

[13] Krampah EA, Yankson K, Blay J. Population dynamics of the Brown mussel Perna perna at a Rocky beach near Cape Coast, Ghana. Marine Ecology. 2019; 00:e12575.

[14] Lamptey E, Armah AK. Factors Affecting Macrobenthic Fauna in a Tropical Hypersaline Coastal Lagoon in Ghana, West Africa. Estuaries and Coasts. 2008; 31:1006.

[15] Micklem JM, Griffiths CL, Ntuli N, Mwale M. The invasive Asian green mussel Perna viridis in South Africa: all that is green is not viridis. African Journal of Marine Science. 2016; 38: 207- 215.

[16] Obodai EA, Yankson K. The present status and potential of the oyster industry in Ghana. Journal of the Ghana Science Association (Special Edition). 1999; 2:66-73.

[17] Sutton AE, Yankson K, Wubah DA. The Effect of Salinity on Particle Filtration Rates of the West African Mangrove Oyster. Journal of Young Investigators. 2012; 24(4): 55-59.

[18] Theisen BF. Infestation of Mytilus edulis by Mytilicola intestinalis. Ophelia. 1987; 27:77-86.

[19] Yankson K. Gonad maturation and sexuality in the West African bloody cockle, Anadara senilis (L). Journal of Molluscan Studies. 1982; 48:294-301.

[20] Yankson K. Sexual differentiation of Crassostrea tulipa in two contrasting brackishwater environments. Journal of Molluscan Studies. 1996; 62:135-137. 
[21] Yankson K, Obodai EA (1999). An update of the number, types, and distribution of coastal lagoons in Ghana. Journal of the Ghana Science Association (Special Edition). 1999; 2: 26-311.

[22] Yankson K. Fish from the shell: its potential in the quest for adequate protein in Ghana. An inaugural lecture delivered at the University of Cape Coast. Accra, Ghana: Media Graphics \& Press Ltd. 2004.

[23] Yoloye V. The habit and functional anatomy of the West African bloody cockle, Anadara senilis. Proceedings of Malacca Society London. 1975; 41:277-299.

* Corresponding author.

E-mail address: faotchere8@y ahoo.ca. 